\title{
Memperkokoh Corporate Culture Melalui Mindset dan Family Value
}

\author{
Gendut Sukarno ${ }^{1}$, Muhamat Nur Mustakim² \\ 1,2,3,4 Universitas Pembangunan Nasional Veteran Jawa Timur, Surabaya, Indonesia \\ Contact: sukarnogendut@yahoo.co.id
}

\begin{abstract}
Some of the most successful companies in Indonesia come from Family Companies that can reach 3 generations. The organizational culture in the family company is largely determined by the mindset of the family company actors. Besides, many family companies cannot articulate their core values (Family Values) into values that can be applied to business, which must be exemplified by company Leaders. This study aims to examine the concepts of Mindset, Family Value, and Leadership in Organizational Culture. The object of this study is a family company which is engaged in building materials business. The population in this study was all employees at building material companies in Surabaya, with a sample of 30 building material company owners as respondents. The analysis technique used in this study is Partial Least Square (PLS). Based on the study results, it shows that (1) mindset has a significant effect on the organizational culture of the building material family company. (2) Leadership has a significant effect on the organizational culture of the building material family company. (3) Family values have a significant effect on the organizational culture of the building material family company in Surabaya.
\end{abstract}

Keywords: Mindset, Leadership, Family Values, Organizational Culture

\begin{abstract}
ABSTRAK
Sebagian perusahaan yang sukses di Indonesia ternyata berasal dari Perusahaan Keluarga yang dapat mencapai 3 Generasi. Budaya organisasi dalam perusahaan keluarga sangat ditentukan oleh Pola Pikir (Mindset) pelaku perusahaan keluarga. Disamping itu banyak perusahaan keluarga tidak mampu mengartikulasikan nilai inti (Family Value) mereka menjadi nilai-nilai yang dapat diterapkan untuk bisnis, yang harus diberikan contoh oleh Pemimpin perusahaan. Penelitian ini bertujuan untuk mengkaji konsep Mindset, Family Value, dan Kepemimpinan terhadap Budaya Organisasi. Obyek dalam penelitian ini adalah perusahaan keluarga yang bergerak dalam bidang Usaha bahan bangunan. Populasi pada penelitian ini adalah seluruh karyawan pada perusahaan bahan bangunan yang ada di Surabaya, dengan sampel sebanyak 30 pemilik perusahaan bahan bangunan sebagai responden. Teknik analisis yang digunakan dalam penelitian adalah Partial Least Square (PLS). Berdasarkan hasil penelitian menunjukkan bahwa (1) mindset berpengaruh signifikan terhadap budaya organisasi perusahaan keluarga bahan bangunan. (2) Kepemimpinan berpengaruh signifikan terhadap budaya organisasi perusahaan keluarga bahan bangunan. (3) Nilai keluarga berpengaruh signifikan terhadap budaya organisasi perusahaan keluarga bahan bangunan di Surabaya.
\end{abstract}

Kata kunci: Mindset, Kepemimpinan, Nilai Keluarga, Budaya Organisasi

\section{Pendahuluan}

Bisnis keluarga merupakan bentuk bisnis tertua dan paling dominan di dunia organisasi bisnis. Bisnis keluarga tidak hanya berkisar pada perusahaan kecil dan menengah namun juga sampai sektor industri tertentu, tetapi perusahaan menengah dan besar serta beroperasi di berbagai sektor industri. Bisnis keluarga merupakan mesin pendorong pembangunan sosialekonomi dan penciptaan kekayaan di seluruh dunia (Panjwani A. Anggarval V, 2008). 
Bisnis keluarga sangat berperan dalam penyerapan tenaga kerja, penyerapan yang dimaksud adalah penarikan tenaga kerja baru untuk megisi sebuah kekosongan pekerjaan. Usaha dengan berlatar belakang bisnis keluarga ternyata telah berkontribusi sebesar $60 \%$ dalam penyerapan tenaga kerja (Samboh, 2011). Hal tersebut akan mampu menjadi peluang bagi sumber daya manusia yang sangat banyak di Indonesia ini agar pengangguran tidak semakin meluas.

Dengan menciptakan binis keluarga akan mampu mendongkrak perekonomian Indonesia dan akan membuka peluang pekerjaan baru. Di Indonesia terdapat 195.000 perusahaan, di mana 95\% dari total jumlah tersebut adalah perusahaan keluarga (Purwanto, 2013). Dari angka tersebut dapat dilihat bahwa usaha indonesia kebanyakan adalah bisnis keluarga dan hal tersebut pastinya akan mampu untuk bersaing dengan negara lainya.

Semakin meningkatnya bisnis keluarga dapat dipastikan memiliki banyak peran yang besar dalam perkembangan perekonomian di Indonesia, Khususnya terkait dengan penyerapan tenaga kerja yang nantinya dapat berdampak pada pembangunan ekonomi bangsa Indonesia. Sebuah perusahaan dapat didefinisikan sebagai perusahaan keluarga apabila (1) kepemilikan perusahaan tersebut hanya dipegang oleh satu keluarga saja, (2) tiga atau lebih anggota dari keluarga tersebut berperan aktif di dalam manajemen perusahaan, dan (3) adanya keterlibatan minimal dua generasi dari keluarga tersebut dalam menetapkan kebijakan perusahaan (Panjwani A. Anggarval V, 2008).

Bisnis keluarga di Indonesia sebagian besar diwarnai oleh Corporate Culture (budaya organisasi) yang sangat kuat digerakkan oleh peran pemimpin/pemilik/pengelola bisnis. Budaya organisasi merupakan sebuah kepercayaan bersama, norma dan nilai yang dimiliki oleh orang-orang dalam sebuah organisasi (Cruz et al., 2012). Suatu budaya organisasi yang kuat dan telah berakar akan dapat memberikan kontribusi yang kuat bagi anggota organisasi dalam hal pemahaman yang jelas tentang permasalahan yang diselesaikan. Budaya memiliki pengaruh yang berarti pada sikap dan perilaku anggota-anggota organisasi.

Dalam era globalisasi yang sangat cepat dengan perubahan dan sangat sulit diprediksi namun sangat besar dampaknya bagi masa depan organisasi, kehadiran budaya organisasi yang kokoh namun fleksibel menjadi sangat mudah. Cara mengatasi perubahan yang akan dilakukan oleh suatu organisasi dengan mempertimbangkan aspek dan nilai budaya yang cocok untuk menghadapi perubahan dimasa depan.

Terbentuknya budaya organisasi di dalam suatu perusahaan tidak dapat dipaksakan. Seseorang harus pelan-pelan untuk dapat merubah budaya oganisasi yang akan diterapkan dan melihat kondisi apakah sasaran mampu untuk menjalankan budaya organisasi tersebut. Sehingga harus sabar untuk dapat menerapkan budaya organisasi perusahaan dengan tepat dan sesuai aturan yang dibuat.

Pola Pikir pelaku binis keluarga pada umumnya terbentuk secara turun temurun hingga beberapa generasi. Pola Pikir atau yang sering disebut Mindset terdiri atas dua kata: mind dan set. "Mind" berarti sumber pikiran dan memori; pusat kesadaran yang menghasilkan pikiran, perasaan, ide, dan persepsi, dan menyimpan pengetahuan dan memori. "Set" berarti mendahulukan peningkatan kemampuan dalam suatu kegiatan. Dengan demikian mindset 
adalah kepercayaan yang mempengaruhi sikap seseorang, sekumpulan kepercayaan atau suatu cara berpikir yang menentukan perilaku dan pandangan, sikap, dan masa depan seseorang) menurut Adi W Gunawan (2007).

Dalam suatu binis keuarga, mindset membentuk sebuah dorongan dan motivasi seseorang untuk dapat bekerja dengan maksimal dan menciptakan sebuah keberhasilan. Besarnya pengaruh mindset tehadap keberhasilan organisasi dibutuhkan seorang pemimpin yang mampu mempengaruhi dan mengendalikan karyawannya agar arahan yang diberikan seorang pemimpin dapat diterima dan dilaksakan dengan baik. Tanpa adanya mindset untuk selalu berkembang, sebuah bisnis akan mengalami penurunan bahkan akan terancam bangkrut. Dalam bisnis keluarga selalu ditanamkan pola pikir untuk selalu dapat mempertahankan bisnis keluarganya untuk terus dapat dijalankan sampai generasi berikutnya. Dalam hal tersebut fungsi dari seorang pemimpin sangat dibutuhkan agar semua tujuan yang telah direncanakan akan dapat berjalan dengan baik.

Menurut Bangun (2012) kepemimpinan merupakan proses mempengaruhi orang lain dalam suatu organisasi agar mereka dapat melaksanakan tugasnya dengan baik dalam mencapai tujuan perusahaan. Kepemimpinan sebagai tulang punggung pengembangan organisasi, karena tanpa pemimpin yang baik akan sulit umtuk mencapai sebuah tujuan. Kepemimpinan selalu berbicara mengenai pengaruh (Maxwell, 2013).

Pola kepemimpinan mempunyai peranan penting dalam meningkatkan sebuah kesuksesan suatu organisasi. Bagaimana tidak, karena sesungguhnya faktor internal yang dapat meninkatkan suatu budaya dalam individu setiap karyawan sehingga mampu bekerja dengan efektif. Hubungan antara pemimpin dan karyawan merupakan hubungan yang saling ketergantungan yang pada umumnya terjadi proses interksi antara pemimpin dan bawahannya berlangsung saling mempengaruhi. Dari interksi inilah yang menentukan derajat keberhasilan pemimpin di dalam kepemimpinannya dalam suatu organisasi.

Robbins (2003) mengungkapkn bahwa teori kepemimpnan yang terkait dengan eratnya hubungan atasan bawahan mengasumsikan bahwa pemimpin memperlakukan para pengikut atau bawahan secara sama. Pemimpin mepergunakan suatu gaya yang sama secara adil terhadap individu dalam unit kerjanya masing-masing. Dengan demikian interksi yang berjalan antara atasan dan bawahan akan semakin lancar dan akan terjalin hubungan yang erat.

Dalam suatu bisnis pemimpin memiliki kewajiban untuk membuat dan menetapkan visi perusahaannya, lalu memberikan arahan bagi karyawannya langkah-langkah apa saja yang harus diambil serta menanamkan nilai-nilai apa yang menjadi dasar dan keyakinannya dalam bertindak yang kemudian dikomunikasikan kepada para karyawan agar dapat bersama-sama mewujudkan visi perusahaan dari sudut pandang yang sama.

Nilai keluarga adalah sistem, sikap dan kepercayaan yang secara sadar atau tidak, mempersatukan anggota keluarga dalam satu budaya (Murwani, 2007). Nilai merupakan seperangkat kebiasaan atau aturan yang diakui kebenarannya oleh suatu anggota organisasi sebagai cara untuk menciptakan kehidupan yang teratur. Sehingga jika nilai dapat ditanamkan dengan baik pelaku bisnis akan menjadi sebuah motivasi yang kuat bagi anggotanya untuk selalu menjaga kebiasaan dan aturan-aturan yang telah diterapkannya. 
Dalam sebuah organisasi terdapat nilai-nilai yang dijadikan pendoman perilaku oleh setiap anggotanya, nilai yang berlaku di tersebut dinamakan nilai sosial. Setiap nilai sosial yang tercipta atas kesepakatan bersama yang dipengaruhi oleh kebudayaan yang dijunjung tinggi secara turun-temurun. Nolai sosial berperan penting dalam mengatur pola perilaku yang baik, seimbang, tidak merugikan, dan tidak menimbulkan ketidakadilan.

Dari nilai- nilai yang telah ditetapkan masih ada kendala yang sebagian dianggap sulit untuk diterapkan oleh pelaku bisnis terutama dalam penerapan sebuah pengambilan keputusan. Pada umumnya banyak bisnis keluarga yang tidak mampu mengartikulasikan nilai inti mereka menjadi nilai-nilai yang dapat diterapkan untuk bisnis sehingga, mengakibatkan perusahaan keluarga sering kali mengalami masalah dalam pengambilan keputusan (Dumas \& Blodgett, 1999).

Para pemimpin bisnis keluarga harus dapat memperhatikan semua aspek untuk mencapai keberhasilan dan suksesi, karena tanpa kemampuan pemimpin dan manajemen dari generasi berikutnya bisnis keluarag tidak dapat berjalan. Sehingga perlu pembakalan pengetahuan, sikap, serta keterampilan yang memungkinkan seseorang dapat mencapai suatu keberhasilan. Peningkatan sumber daya manusia menentukan seberapa lama bisnis keluarga dapat berjalan lamanya, artinya semakinn tinggi pengetahuan dan kemapuan mengelola bisnis sebuah organusasi akan terus berjalan.

Usaha bahan bangunan merupakan salah satu usaha yang dibentuk dari sekumpulan keluarga yang secara history berasal dari keluarga Muslim. Silsilah keluarga tersebut biasanya dari Suami, istri, anak, menantu, dan keluarga dekat lainnya, dengan beberapa tenaga kerja non keluarga sebagai pekerja kasar.

\section{Hasil dan Pembahasan}

\section{Pengujian Model Pengukuran (Outlier Model)}

Tabel 1. Outer Loadings (Mean, STDEV, T-Values)

\begin{tabular}{lccccc}
\hline & $\begin{array}{c}\text { Factor } \\
\text { Loading (O) }\end{array}$ & $\begin{array}{c}\text { Sample } \\
\text { Mean (M) }\end{array}$ & $\begin{array}{c}\text { Standard } \\
\text { Deviation (STDEV) }\end{array}$ & $\begin{array}{c}\text { Standard } \\
\text { Error } \\
\text { (STERR) }\end{array}$ & $\begin{array}{c}\text { T Statistics } \\
\text { (|O/STERR I) }\end{array}$ \\
\hline X1.1<- Mindset (X1) & 0,85812 & 0,8613 & 0,02957 & 0,02957 & 29,019797 \\
\hline X1.2<- Mindset (X1) & 0,84015 & 0,8154 & 0,100939 & 0,10094 & 8,323338 \\
\hline X1.3<- Mindset (X1) & 0,7969 & 0,7646 & 0,117145 & 0,11715 & 6,80268 \\
\hline X1.4<- Mindset (X1) & 0,81336 & 0,7976 & 0,069351 & 0,06935 & 11,728115 \\
\hline X2.1<- Kepemimpinan (X2) & 0,61568 & 0,6219 & 0,075534 & 0,07553 & 8,151039 \\
\hline X2.2<- Kepemimpinan (X2) & 0,82649 & 0,8232 & 0,039959 & 0,03996 & 20,683479 \\
\hline X2.3<- Kepemimpinan (X2) & 0,86703 & 0,8607 & 0,031696 & 0,0317 & 27,354608 \\
\hline X2.4<- Kepemimpinan (X2) & 0,69408 & 0,6927 & 0,061563 & 0,06156 & 11,274314 \\
\hline X3.1<- Nilai keluarga (X3) & 0,87806 & 0,8798 & 0,025539 & 0,02554 & 34,380591 \\
\hline X3.2<- Nilai keluarga (X3) & 0,86064 & 0,8638 & 0,023766 & 0,02377 & 36,213169 \\
\hline X3.3<- Nilai keluarga (X3) & 0,79739 & 0,7977 & 0,048963 & 0,04896 & 16,285427 \\
\hline Y1.1<- Budaya organisai (Y) & 0,79485 & 0,7939 & 0,037498 & 0,0375 & 21,197041 \\
\hline Y1.2<- Budaya organisai (Y) & 0,76348 & 0,7622 & 0,046647 & 0,04665 & 16,36718 \\
\hline Y1.3<- Budaya organisai (Y) & 0,73515 & 0,7274 & 0,059514 & 0,05951 & 12,352643 \\
\hline Y1.4<- Budaya organisai (Y) & 0,75639 & 0,7539 & 0,051195 & 0,0512 & 14,774665 \\
\hline
\end{tabular}

Sumber: Data Diolah 
Berdasarkan pada tabel outer loading di atas, seluruh indikator reflektif pada variable Mindset (X1), Kepemimpinan (X2), Nilai Keluarga (X2), dan Budaya Organisasi (Y), menunjukan factor loading (original sample) lebih besar dari 0,50 dan atau signifikan (Nilai T-Statistic lebih dari nilai $Z \alpha=0,05(5 \%)=1,96)$, dengan demikian hasil estimasi seluruh indikator telah memenuhi Convergen vailidity atau validitasnya baik.

\section{Average variance extracted (AVE)}

Tabel 2. Average variance extracted (AVE)

\begin{tabular}{lc}
\hline & AVE \\
\hline Budaya Organisasi (Y) & 0,581817 \\
Kepemimpinan (X2) & 0,573907 \\
Mindset (X1) & 0,684710 \\
Nilai Keluarga (X3) & 0,715833 \\
\hline
\end{tabular}

Sumber: Data Dolah

Hasil pengujian AVE untuk variabel Mindset (X1) sebesar 0,684710, variabel Kepemimpinan (X2) sebesar 0,573907, variabel Nilai Keluarga (X3) sebesar 0,715833, dan Budaya Organisasi (Y) sebesar 0,581817, keempat variabel tersebut menunjukkan nilai lebih dari 0,5 , jadi secara keseluruhan variabel dalam penelitian ini dapat dikatakan validitasnya baik.

\section{Composite Reliability}

Tabel 3. Composite Reliability

\begin{tabular}{lc}
\hline & Composite Reliability \\
\hline Budaya Organisasi (Y) & 0,847580 \\
Kepemimpinan (X2) & 0,841070 \\
Mindset (X1) & 0,896690 \\
Nilai Keluarga (X3) & 0,882966 \\
\hline
\end{tabular}

Sumber: Data Diolah

Hasil pengujian Composite Reliabilitymenunjukkan bahwa variabelvariabel Mindset(X1) sebesar 0,896690, variabel Kepemimpinan(X2) sebesar 0,841070, variabel Nilai Keluarga (X3) sebesar 0,882966, dan Budaya Organisasi (Y) sebesar 0,847580, keempat variabel tersebut menunjukkan nilai Composite Reliabilitydiatas 0,70 sehingga dapat dikatakan seluruh variabel pada penelitian ini reliabel.

\section{Hasil dari Inner Weights}

Selanjutnya untuk pengujian hipotesis dapat dilihat hasil koefisien dan nilai T-statistic dari inner model pada tabel berikut ini. 
Tabel 4. Path Coefficient (Mean, STDEV, T-Value

$\begin{array}{ccccc}\begin{array}{c}\text { Path } \\ \text { Coefficients }\end{array} & \text { Sample } & \text { Standard } & \text { Standard } & \text { T Statistics } \\ \text { (O) } & & \begin{array}{c}\text { Deviation } \\ \text { (STDEV) }\end{array} & \begin{array}{c}\text { Error } \\ \text { (STERR) }\end{array} & \begin{array}{c}\text { (|O/STERR |) } \\ \text { (ST) }\end{array}\end{array}$

\begin{tabular}{|c|c|c|c|c|c|}
\hline $\begin{array}{l}\text { Mindset }(\mathrm{X} 1) \text {-> Budaya } \\
\text { Organisasi }(\mathrm{Y})\end{array}$ & 0,124195 & 0,131118 & 0,057894 & 0,057894 & 2,145208 \\
\hline $\begin{array}{l}\text { Kepemimpinan (X2) -> } \\
\text { Budaya Organisasi (Y) }\end{array}$ & 0,535120 & 0,540239 & 0,104694 & 0,104694 & 5,111279 \\
\hline $\begin{array}{l}\text { Nilai Keluarga (X3) -> } \\
\text { Budaya Organisasi (Y) }\end{array}$ & 0,232429 & 0,224022 & 0,095364 & 0,095364 & 2,437286 \\
\hline
\end{tabular}

Sumber: Data Diolah

\section{Keterangan :}

1. Mindset berpengaruh positip terhadap Budaya Organisasi perusahaan keluarga bahan bangunan.

2. Kepemimpinan berpengaruh positip terhadap Budaya Organisasi perusahaan keluarga bahan bangunan.

3. Nilai Keluarga (Family Value) berpengaruh positip terhadap Budaya Organisasi perusahaan keluarga bahan bangunan.

\section{Analisis Model PLS}

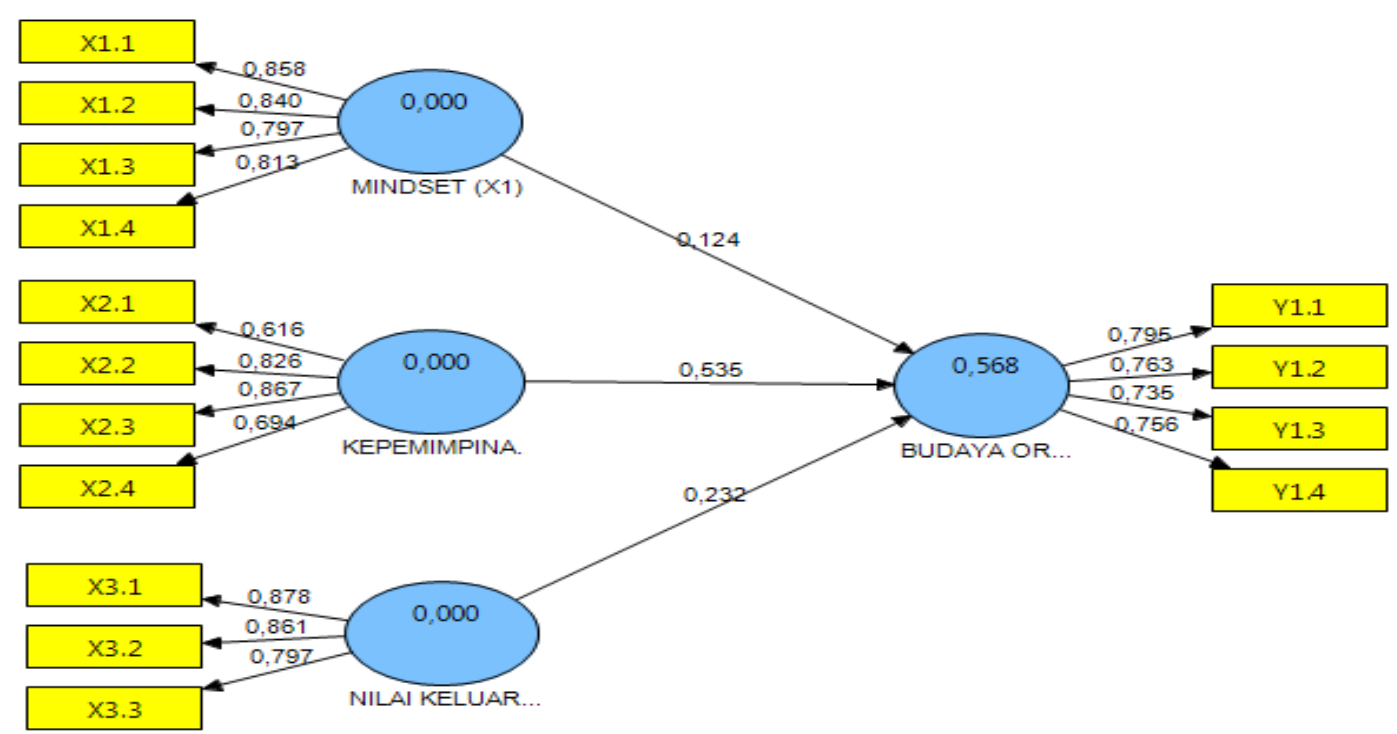

Gambar 2. Outer Model dengan factor loading,Path Coefficient dan R-Square Sumber : olah data, output SmartPLS

\section{Pembahasan Penelitian}

\section{Pengaruh Mindset Terhadap Budaya Organisasi}

Berdasarkan data dari tabel 4 dapat diketahui bahwa variabel mindset beserta indikator berpengaruh terhadap budaya organisasi perusahaan keluarga bahan bangunan. Indikator yang paling dominan terhadap budaya organisasi adalah tanggung jawab pribadi. Dengan ini 
dapat dikatakan bahwa mindset berpengaruh positif terhadap budaya organisasi perusahaan keluarga bahan bangunan.

Mindset merupakan salah satu dari berbagai faktor yang mempengaruhi budaya organisasi, oleh sebab itu perusahaan keluarga bahan bangunan menanamkan dan melatih mindset karyawan untuk selalu mentaati dan menerapkan peraturan yang telah dibuat walaupun tidak diawasi oleh pimpinan. Hal ini sesuai dengan teori yang dikemukakan oleh Anderson \& Anderson (2001) Budaya merupakan akumulasi dari keseluruhan mindset dari setiap individu yang digabungkan menjadi serangkaian kesepakatan bersama. Dengan ini dijelaskan apabila seamakin baik mindset yang ditanamkan pada karyawan akan semakin meningkat pula budaya organisasi dapat diterapkan.

Hasil penelitian ini didukung dari penelitian yang dilakukan oleh Dede, Paud Mansur (2016) menunjukan bahwa variabel mindset berpengaruh positif dan signifikan terhadap variabel budaya organisasi.

\section{Pengaruh Kepemimpinan Terhadap Budaya Organisasi}

Berdasarkan data dari tabel 4 dapat diketahui bahwa variabel kepemimpinan beserta indikator berpengaruh terhadap budaya organisasi di perusahaan keluarga bahan bangunan. Indikator yang paling dominan terhadap budaya organisasi adalah kemampuan memimpin. Dengan ini dapat dikatakan bahwa mindset berpengaruh positif terhadap budaya organisasi di perusahaan keluarga bahan bangunan.

Kepemimpinan sebagai salah satu faktor yang mempengaruh budaya organisasi, kekuasaan dari pemimpinan sangat membantu untuk mengatur dan mengarahkan karyawan untuk dapat menjalankan budaya organisasi perusahaan. . Hal ini sesuai dengan teori yang dikemukakan Wibowo (2010) budaya organisasi tumbuh dan berkembang bersama pendiri dan pemimpin organisasi, di mana kepemimpinan yang dimiliki merupakan kunci untuk menanamkan budaya korporasi yang kuat.

Hasil penelitian ini senada yang dilakukan oleh Bayu Ratno Tenggara Dkk (2016). menunjukan bahwa variabel kepemimpinan berpengaruh positif dan signifikan terhadap variabel budaya organisasi.

\section{Pengaruh Nilai Keluarga Terhadap Budaya Organisasi}

Berdasarkan data dari tabel 4 dapat diketahui bahwa variabel nilai keluarga (Family Value) beserta indikator berpengaruh terhadap budaya organisasi di perusahaan keluarga bahan bangunan. Indikator yang paling dominan terhadap budaya organisasi adalah berbagi tanggung jawab. Dengan ini dapat dikatakan bahwa mindset berpengaruh positif terhadap budaya organisasi di Perusahaan keluarga bahan bangunan.

Nilai keluarga sebagai salah satu faktor yang mempengaruhi budaya organisasi, degan nilai keluarga yang kuat akan membuat karyawan lebih kompak dan mudah menjalakan budaya organisasi yang diterapkan. Hal ini sesuai dengan teori yang dikemukakan Efferin dan Hartono (2015) menyimpulkan bahwa kontrol budaya berdasarkan nilai keluarga merupakan yang paling dominan. 
Penekitian ini sejalan dengan penelitian yang dilakukan oleh Maria Bela, Maichel (2018) menunjukan bahwa variabel nilai keluarga berpengaruh positif dan signifikan terhadap variabel budaya organisasi.

\section{Simpulan}

Mindset mampu memberikan kontribusi terhadap budaya organisasi pada perusahaan keluarga bahan bangunan. Hal ini mengidentifikasi bahwa seamakin besar mindset yang ditanamkan pada diri karyawan akan mempermudah perusahaan untuk menerapkan budaya organisasi yang di terapkan agar mudah diterima dan dilaksanakan dengan baik. Kepemimpinan mampu memberikan kontribusi terhadap budaya organisasi, mengidentifikasi bahwa semakin besar tingkat kepemimpinan yang diterapkan akan memberikan dampak baik bagi seluruh karyawan dan mampu memberikan dorongan-dorongan untuk mentaati peraturan perusahaan sehingga budaya organisasi dapat terlaksana sesuai kenginan perusahaan. Nilai keluarga mampu memberikan kontribusi terhadap budaya organisasi. Hal ini mengidentifikasi bahwa dengan adanya jalinan nilai keluarga yang kuat pada diri karyawan akan membuat meraka lebih kompak dan mudah menjalankan budaya organisasi yang diterapkan perusahaan.

\section{Daftar Pustaka}

Adi W. Gunawan. (2007). The Secret of Mindset. Jakarta: Gramedia Pustaka Utama.

Anoraga, P. 2005. Psikologi Kerja. Jakarta: Rineka Cipta. Anoraga, Pandji dan Sri Suyati. 1995. Perilaku Keorganisasian. Jakarta: PT. Dunia Pustaka Jaya.

Bangun, W. (2012). Manajemen Sumber Daya Manusia. Jakarta: Erlangga.

Cruz, A. D., Hamilton, E., \& Jack, S. L. (2012). Understanding entrepreneurial cultures in family businesses: a study of family entrepreneurial teams in Honduras. Journal of Family Business Strategy, 3, 147-161. https://doi.org/10.1016/j.jfbs.2012.05.002

Dumas, C., \& Blodgett, M. (1999). Articulating values to inform decision making: lessons from family firms around the world. International Journal of Value-Based Management, 12(3), 209-221. https://doi.org/10.1023/A:1007764112498

Fahrudin, A. (2012). Keberadaan fungsi keluarga: konsep dan indikator pengukuran dalam penelitian. Jurnal Informasi, 17(2), 75-81.

Hasibuan, Malayu SP, 2009, Manajemen Sumber Daya Manusia, Dasar dan Kunci Keberhasilan, Cetakan Keenam, CV. Haji Masagung, Jakarta.

Koiranen, M. (2002). Over 100 years of age but still entrepreneurially active in business: exploring the values and family characteristics of old finnish family firms. Family Business Review, 15(3), 175-188. https://doi.org/10.1111/j.1741-6248.2002.00175.x

Lussier N Robert (2010), Human Relation in Organization Applications and Skill Building. New York: Mc. Graw Hill

Maxwell, J. C. (2012). The Five Levels of Leadership. Surabaya: PT Menuju Insan Cemerlang.

Murwani, A. (2007). Asuhan Keperawatan Keluarga: Konsep dan Aplikasi Kasus. Yogyakarta: Mitra Cendikia Press. 
Panjwani A, and Anggarval V,2008. Family business: Yesterday, today, tomorrow, January 2008, Indian journal of industrial relations 44(2):272-291

Purwanto, D. (2013). Perusahaan keluarga haram lakukan affair dengan penguasa. Diakses 23 Agustus, 2016, dari http://bisniskeuangan.kompas.com/read/ 2013/02/18/14573668/Perusahaan.Keluarga.Haram.Lakukan.Affair.dengan.Penguasa.

Robbins, Stephen. 2008, Organization Behaviour, Tenth Edition ( Perilaku Organisasi Edisi ke Sepuluh), Alih Bahasa Drs. Benyamin Molan. Jakarta: Salemba Empat

Rivai, V., \& Mulyadi, D. (2012). Kepemimpinan dan Perilaku Organisasi (3 ed.). Jakarta: Rajawali Pers.

Samboh, E. (2011). RI Businesses Dominated by Families. Diakses 22 Agustus, 2016, dari http://www.thejakartapost.com/news/2011/11/01/ri-businesses-dominated-byfamilies.html.

Stogdill, 1974, Handbook of Leadership: A Survey of Theory and research. New York Free Press dalam Kartini Kartono, 1994. Psikologi Sosial untuk Manajemen, Persahaan dan Industri. Jakarta: Rajawali Press.

Wibowo. (2010). Budaya Organisasi: Sebuah Kebutuhan untuk Meningkatkan Kinerja Jangka Panjang (1 ed.). Jakarta: Rajawali Pers. 